\title{
Alasdair Mòr mac an Rìgh: A Reassessment of Alexander Stewart's Political Disposition During the Reign of Robert II of Scotland
}

Michael Ruiter

\begin{abstract}
In the late thirteenth and early fourteenth centuries, the north of Scotland was, according to popular history, terrorized by the king's son, Alexander Stewart. Known more commonly by the name Wolf of Badenoch, Alexander is remembered as a defier of royal rule, and a scourge upon the lords of the north. This paper seeks to unravel some of the complicated political relationships operating at this time, and to define specifically, that between Robert Stewart II and his son, Alexander Stewart.
\end{abstract}

Alexander Stewart, lord of Badenoch, earl of Buchan, and third son of King Robert II of Scotland has been given the historical designation, Wolf of Badenoch. The lowland chronicler, Abbot Walter Bower, claimed that this byname was commonly used for Alexander Stewart: a name representative of his violent, dangerous, and unpredictable rule in the north of Scotland. ${ }^{1}$ So notorious is Badenoch's historical representation, that he has been termed by P. F. Tytler, a "species of Celtic Attila" who "issued from his lair in the north . . . to scourge and afflict the nation." Alexander, however, was also known by another designation. In curious opposition to the Wolf of Badenoch, he has also been called Alasdair Mòr mac an Righ or, Great Alexander Son of the King. ${ }^{3}$ Badenoch has traditionally been characterized as negatively affecting Robert II's reign by causing chaos in the north, and in so doing, destabilizing Robert II's rule. ${ }^{4} \mathrm{~A}$ careful reexamination of the history of Alexander Stewart reveals that he may not have been quite the lupine character he has so often been called.

Tracing, in a roughly chronological order, Alexander's relationship with his father, one can glean evidence suggesting positive and cooperative ties between them. This cooperation was particularly manifested in the shared rivals of Robert II and Alexander in northern Scotland. Foremost among these rivals was the Lindsay/Leslie affinity, which complicated much of Alexander and Robert II's power in the north. ${ }^{5}$ As an extension of this rivalry, an analysis of Alexander Stewart's curious relationship with Euphemia, countess of Ross, after the death of her husband, Walter Leslie, reveals the possibility for further cooperative political manoeuvres by

1. Stephen Boardman, "Lordship in the North-East: The Badenoch Stewarts I. Alexander Stewart, Earl of Buchan, Lord of Badenoch," Northern Scotland: The Journal for Scottish Studies, University of Aberdeen, ed. Peter L. Payne, vol. 16 (1996): 1.

2. Boardman, "Lordship in the North-East," 1. In which he draws the quotation from P. F. Tytler's The History of Scotland from the Ascension of Alexander III to the Union.

3. Ibid., 8-9.

4. Alexander Grant, "Thanes and Thanages, From the Eleventh to the Fourteenth Centuries" in Medieval Scotland: Crown, Lordship and Community, ed. Alexander Grant and Keith J. Stringer, (Edinburg: Edinburgh University Press, 1993), 70-1. While Boardman seems to take a more neutral position with regard to Alexander Stewart's effects on Robert II's rule, older scholarship, of which Grant is a fairly representative example, varies in representing Alexander as exercising power in a way counteractive to Robert II's rule, or in a way free from influence, as Robert II cared little for the way in which the north was governed. Boardman has gone through great lengths to show the latter to be false.

5. Stephen Boardman, The Stewart Dynasty in Scotland: The Early Stewart Kings: Robert II and Robert III 1371-1406 (East Linton: Tuckwell Press, 1997), 47-8. 
the King and Alexander. ${ }^{6}$ Finally, a brief investigation into the roles played by the King's two elder sons-John, earl of Carrick and Robert, earl of Fife-reveals further evidence for Alexander Stewart's maintenance of stability in the north, and support of his father, King Robert II's reign.

Firstly, it is necessary to contextualize the political situation in Scotland before discussing Alexander and Robert II's relationship. The political standing of Robert Stewart - henceforth referred to as Steward when regarding his life prior to his coronation - in mid-fourteenth century Scotland was a complicated one. Steward of Scotland, and nephew to then-king David II, Robert's power was in a delicate balance with that of the King. ${ }^{7}$ This became more apparent toward the end of David II's reign. ${ }^{8}$ Having no male heir and already into his forties, David II may have been worried of Steward's impending inheritance of the crown which had been made official in a 1318 settlement of succession "with the unanimous consent of one and all of the community." This looming lack of issue, combined with full support for Steward as the future king, put severe strains on the relationship between himself and David II.

Further complicating Scotland's political theatre in the first half of the fourteenth Century, was a complete overturning of lords in the northeast of Scotland. ${ }^{10}$ One effect of this political upheaval was "the declining influence and effectiveness of comital and lordly families rooted in the aristocratic culture and values of lowland Scotland [which] was reflected in the emergence of assertive, aggressive and politically semi-independent Gaelic kindreds." 11 The increased power of the aggressive Gaelic populations of the north was associated with Steward and his sons. This association, combined with David and Robert's strained relationship, was likely the cause for Robert II's imprisonment in late $1368 .{ }^{12}$

This imprisonment followed a warning issued in a June parliament of that year in which David II ordered Steward and his two eldest sons, Carrick and Fife, to pledge themselves to control the inhabitants of their lordships. ${ }^{13}$ Evidently, Steward failed to keep those in his realm, almost certainly the violent Gaels mentioned above, in check, and was imprisoned for several months as a result. ${ }^{14}$ Interestingly, although this warning was issued to Robert Steward and his two eldest sons, it was Alexander, Robert's third son, who was imprisoned with him. ${ }^{15}$ By itself, this is not evidence enough to suggest that during his rule, Robert II was supported by Alexander, but it serves in providing a foundation for evidence of their strong relationship in the fact that they

6. Boardman, Early Stewart Kings, 77.

7. Ibid., 44-7.

8. Maurice Ashley, The House of Stewart: Its Rise and Fall (London: J.M. Dent and Sons Limited, 1980),

26-8. In addition to an overview of the power held by each man, Ashley recounts how David II made a bid for king Edward II of England to succeed him in place of Robert Stewart.

9. "1315, 1318 Settlement of Succession," in Scottish Historical Documents, edited by Gordon Donaldson (New York: Barnes \& Noble, Inc., 1970), 53-4.

10. Boardman, "Lordship in the North-East," 3.

11. Ibid., 3.

12. Boardman, Early Stewart Kings, 73.

13. Ibid., 73.

14. Ibid., 73.

15. Ibid., 73. 
were legally held accountable for the same actions thereby suggesting a cooperation in their ruling endeavours.

In addition to spending several months imprisoned in the court of King David II, after their release, there is evidence Robert Steward was grooming Alexander for his later succession of Badenoch or, at the very least, that the two shared an overlapping power in the region. This can be seen through the joint issuance of letters from Ruthven in 1370 for the protection of Alexander, bishop of Moray's lands and people in Strathspey and Badenoch. ${ }^{16}$ The letters themselves were issued by Alexander Stewart, while the seal they bore was that of Robert Steward, thus hinting at an executive cooperation. ${ }^{17}$ Alternatively, this may suggest Robert's mistrust of Alexander with the rule of this region, and his attempts to ensure his son did as bidden in issuing letters for the bishop's protection against the Gaels with whom Alexander, but not Robert, was associated. Given the fact that Alexander Stewart came to directly inherit the seat of Steward's power in the north however, this joint issuance of letters of protection is more indicative of Steward's trust of Alexander, rather than of divergent ambitions. ${ }^{18}$

Previous scholarship often seeks to explain Alexander's raiding and violence in the north on the basis of discontent with his political position in comparison with that of his brothers. ${ }^{19}$ This is a rather unfounded presumption considering a third son would likely have known his lot would be less than that of his two elder brothers. It is worth noting, however, that even his younger, halfbrother, received a comital title before Alexander did. ${ }^{20}$ This too can be countered with a reminder that power does not necessarily lie with the holder of a title. Indeed, despite his lack of titles, Alexander came to possess vast power and, by 1387 had become "unquestionably the most powerful figure in northern Scotland." 21 Alexander's inheritance should not, therefore be seen solely on the grounds of being lesser than that of his older brothers, but should be interpreted with the knowledge that he directly inherited the traditional heartland of Stewart power-a region characterized by instability for much of the fourteenth Century, and one likely requiring an adept hand to maintain control in the face of this instability. ${ }^{22}$ Such an adept hand, of course, would benefit greatly from cooperation: namely, the coordinated efforts by Alexander and Robert Steward in maintaining Stewart dominance in the region.

\section{II}

In addition to the Gaelic populations threatening the stability of northern lordships, the Lindsay/Leslie affinity was poised to upset the tenuous Stewart control over northern Scotland. The Lindsay/Leslie affinity, a power bloc supported by and loyal to, King David, were longtime rivals of the Stewart claims in the north. ${ }^{23}$ Although this paper attributes more power to this

16. Boardman, Early Stewart Kings, 72-3.

17. Ibid., 72-3.

18. Ibid., 72-4. Boardman makes no attempts in discerning the loyalty between Alexander and Robert Steward, he simply outlines the nature of Alexander's inheritance of Steward's power base in the north.

19. Ibid., 73-4. Boardman cites Alexander Grant's argument that Badenoch would have felt slighted for not receiving the earldom of Moray - held by Robert II himself before being granted to John Dunbar-when both his older brothers had already received earldoms.

20. Ibid., 72, 74-5.

21. Boardman, Early Stewart Kings, 79.

22. Boardman, "Lordship in the North-East," 7-15.

23. Boardman, Early Stewart Kings, 46-8. 
group than previous scholars, it does not do so unfoundedly. Borrowing the term from Stephen Boardman, who suggests longterm consequences for King Robert II resulting from the rivalrous Lindsay/Leslie affinity, the term is here expanded to include the affinity's allies in resistance to Stewart power: some Douglas lords, the bishops of Aberdeen and Moray, John Dunbar, earl of Moray, and various others as loyalties shifted. ${ }^{24}$ Although their actions prevent the group being termed 'unified,' there seems to have been cooperation among them as suited their needs at any given time. After the death of King David II, for instance, in the three months it took for Robert II to be crowned king, despite his previously legislated right to succeed David II, there was resistance spearheaded by William, earl of Douglas, to revive the Balliol and Comyn claims to the throne. ${ }^{25}$ Having been in positions of favour in David II's court, the Lindsay/Leslie affinity was also in opposition to Robert II's claim. ${ }^{26}$ This opposition however, was bargained away by Robert II giving James and Alexander Lindsay justiciarship north of the Forth, a position held by Alexander Lindsay alone from 1374 until his death in 1382. ${ }^{27}$ Boardman asserts that "the justiciarship north of the Forth was one of the key concessions offered by Robert II to the Lindsay/Leslie affinity for their support or acquiescence during the succession dispute of 1371."28 Bargaining his way to the throne in early 1371, Robert's concessions to the Lindsay/Leslie affinity left a growing power in the north to rival that left to his son, Alexander Stewart, for more than a decade. In this way, the Lindsay/Leslie affinity was a real threat, with real power to rival both Robert II and Stewart power in general. ${ }^{29}$

Despite these concessions on the part of Robert II, there was a lingering resistance to Stewart power in the north by this affinity. Following his return from a crusade of which David II had been a supporter, Walter Leslie was granted several lands and titles, and the hand in marriage of Euphemia, countess of Ross. ${ }^{30}$ Euphemia's father, William, earl of Ross and brother-in-law of Robert II, although against the marriage, was intimidated into acquiescence by King David II. ${ }^{31}$ So intent was David II on this match, that he issued a papal dispensation for their marriage himself. $^{32}$ This engineering of Walter Leslie's inheritance of Ross titles was met with a campaign by William Ross to secure various parts of his inheritance against Walter Leslie. ${ }^{33}$ With this campaign cut short upon William, earl of Ross's death in February 1372, and Walter Leslie out of the country at the time, it was in the same year that Robert II granted Alexander Badenoch lieutenancy over a large portion of northern Scotland, including Ross. ${ }^{34}$ Not only did

\section{Ibid., 124.}

25. F. J. Amours, ed. The Original Chronicle of Andrew of Wyntoun, Vol. XI, Texts: Book VIII [CH. XXV-XL] and IX (Edinburgh: William Blackwood and Sons, 1908), 264-7 (Cottonian Manuscript IX. i. 1-40). For an analysis of the passage: Boardman, Early Stewart Kings, 40-43. It is unclear whether Douglas wanted the crown for himself, Edward II of England, or John of Gaunt, although Boardman suggests the last two as more likely given serious discussion for them as heirs in the last decade of David II's reign.

26. Boardman, Early Stewart Kings, 45-8. Most instrumental in opposition to Douglas were Sir Robert Erskine and the Dunbar brothers (George, earl of March and John, lord of Fife).

27. Ibid., 48 .

28. Ibid., 48.

29. Ibid., 48.

30. Boardman, Early Stewart Kings, 46-7.

31. Ibid., 46-7.

32. Bruce Webster, ed., The Acts of David II King of Scotts, 1329-1371 (Edinburgh: Edinburgh University Press, 1982), 48.

33. Boardman, "Lordship in the North-East," 11.

34. Boardman, Early Stewart Kings, 74-5. Walter Leslie's absence from Scotland is presumed on the issuance of a safe conduct he received for England in February of the same year. 
Alexander Stewart's new position allow a check to Lindsay/Leslie power in that region on the basis of upholding the common law, but Badenoch was also upholder of the terce rights of William's widow, Mary of the Isles, allowing him to directly oppose Walter Leslie's inheritance in continuation of his father's "long-established political animosity" toward the man. ${ }^{35}$ This stalwart protection of Stewart power in northern Scotland is hardly indicative of a son whose exercise of power was detrimental to Robert II's rule.

Further supporting claims of cooperation between Robert II and Alexander, lord of Badenoch, are the results of a settlement of sorts being reached with Sir Walter Leslie. The fact that father and son shared views of Walter Leslie both as a dangerous political rival and, when a settlement was made, as just another title holder, suggests that Alexander's actions against Walter Leslie were not arbitrary or spiteful, but rather in targeted assistance of his father, Robert II, in an effort to aid his kingship. Although no details of any settlement survive, by the summer of 1374 Walter Leslie and Alexander Stewart had planned a pilgrimage together, and less than a year later, Leslie established a hold over some elements of his Ross inheritance. Given the enormous favour David II held him in, and the power that would come with the full Ross inheritance, it is reasonable to assume that Walter Leslie may have been the most powerful member of the Lindsay/Leslie affinity. ${ }^{36}$ The apparent establishment of a positive relationship with Walter Leslie is therefore indicative of some sort of mutually beneficial settlement being reached, likely a checking of Lindsay/Leslie ambition as a whole in exchange for permission of Leslie's inheritance. Regarding the rest of the Lindsay/Leslie affinity, one must consider the likelihood that, although evidently held in check with Walter Leslie's position and newfound tolerance for the Stewarts, they would not have been entirely content with any settlement that was reached.

With Walter Leslie content not to push for more power in northern Scotland, not to mention his frequent absences from the country in the 1370s, the deaths of himself and Alexander Lindsay, justiciar north of the Forth, would no doubt have upset the balance of power in northern Scotland. ${ }^{37}$ Walter Leslie died shortly after Alexander Leslie in February 1382, and with the delicate balance of power between the Stewarts and the Lindsay/Leslie affinity now in jeopardy, it was with a desire for stability in mind that Alexander Stewart married Euphemia, countess of Ross, the widow of Walter Leslie, a scant four months later in July of the same year. ${ }^{38}$

In the brief interim between marriages, rather than allies of the Lindsay/Leslie affinity, it was Alexander Badenoch's men who were present in Euphemia's issuance of a grant, thereby suggesting an immediate interest in the fate of the late Walter Leslie's holdings. ${ }^{39}$ This presence of Badenoch's men, rather than those of her husband's affinity, may be evidence that Euphemia of Ross was more inclined to work with the Stewarts. Supporting this possibility, is the fact that Euphemia, mirroring the sentiments of her father, may have felt forced into her marriage with Walter Leslie. ${ }^{40}$ She may have even wished to uphold direct control of her estates following the

35. Ibid., 75 .

36. Boardman, Early Stewart Kings, 76. Boardman claims Walter Leslie and his half-brother, Alexander Lindsay, justiciar north of the Forth, to have headed the Lindsay/Leslie affinity.

37. Ibid., 76.

38. Boardman, Early Stewart Kings, 77.

39. Ibid., 77. Although the grant is dated to 30 April 1379, Boardman provides convincing evidence of the impossibility of that date on the basis of mention of Euphemia's widowhood and Alexander Stewart's titles at the time (Ibid., 101).

40. Ibid., 46. 
actions of her mother, Mary of the Isles, when she had been widowed. ${ }^{41}$ Alternatively, it may not have been by choice, but by some ploy or use of force by Alexander Stewart to assume direct influence over, or control of, the state of Walter Leslie's inheritances. ${ }^{42}$ In any case, from her husband's death, Euphemia, countess of Ross felt the presence of Alexander Stewart in her lifeif only an indirect presence-which is indicative of his interest in the future of Walter Leslie's estates and what such a future would mean for the Stewarts. ${ }^{43}$

In early July, Papal dispensation was granted by Pope Clement VII of Avignon to the bishop of Aberdeen for the marriage of Alexander Stewart and Euphemia, countess of Ross from the impediment to marriage resulting from their shared third and fourth degrees of consanguinity. ${ }^{44}$ A mere decade later, Clement VII directly issued a mandate to several Scottish bishops to enquire into the marriage of Alexander Badenoch and Euphemia on the basis that "they remained together only for a short time and the marriage [had] been the cause of wars, plundering, arson, murders, and many other damages and scandals." 45 These scandals included Alexander living with another woman-by whom he had sired, and was likely to continue siring, several children - as well as the murder of two of King Robert II's men. ${ }^{46}$ These 'scandals,' viewed with scrutiny, are further indication of Alexander Stewart's stalwart loyalty to the king, and that his actions, even if detrimental to the stability of his personal rule, were aimed at securing Stewart power as a whole.

Not only did Alexander and Euphemia's marriage occur remarkably soon after the death of her husband, but the match was conducted with the "full support of Robert II.",47 The King himself travelled not to attend the marriage ceremony, but to attend the transfer of Euphemia's lands to his own possession. ${ }^{48}$ Any lordships not given directly to the King, were to be jointly held by Euphemia and Alexander and to be inherited by any heirs between them. ${ }^{49}$ If they failed to produce an heir, the inheritances would default to Euphemia's son by Walter Leslie, Alexander Leslie. $^{50}$ Regardless of his part in it, this means of securing power away from the Lindsay/Leslie affinity may not have been entirely supported by Alexander Badenoch. Known as either Mariette Nilzarre or Mairead inghean Eachainn, the woman with whom his cohabitation was termed a 'scandal' was tied to Alexander Badenoch in "what was surely a Gaelic secular marriage." " Boardman insists that this woman with whom the Pope accused Badenoch of living in concubinage, was actually his wife of a sort and had likely produced the first of Alexander's children, Alexander earl of Mar, by $1373 .{ }^{52}$ Although not making any claims as to whether all his children were by the same woman, Boardman seems convinced that she was the mother of

41. Ibid., 75 .

42. Ibid., 75-9. The accounts suggesting that Alexander Stewart kidnapped Euphemia and forced her to accept marriage to him are likely based on this view.

43. Ibid., 77.

44. Clement VII of Avignon, Calendar of Papal Letters to Scotland of Clement VII of Avignon 1378-1394, ed. Charles Burns (Edinburgh: T. And A. Constable Limited, 1976), 79.

45. Clement VII of Avignon, Calendar of Papal Letters, 174. The bishops in question were those of St. Andrews, Glasgow, and Aberdeen.

46. Ibid., 174, 181.

47. Boardman, Early Stewart Kings, 77.

48. Ibid., 77.

49. Ibid., 77-8.

50. Boardman, Early Stewart Kings, 78.

51. Boardman, "Lordship in the North-East," 9.

52. Boardman, Early Stewart Kings, 56. 
some of Badenoch's children, including the eldest, Alexander who would later become earl of Mar. ${ }^{53}$ Given the likelihood that the eldest of his children was sired by his secular wife, and their continued cohabitation into the $1390 \mathrm{~s}$, it is not unreasonable to suggest their secular marriage had all the markings of an ecclesiastical one. The longstanding status of Alexander and Mairead's marriage, coupled with the apparent facade of his marriage with Euphemia - not to mention the widespread political consequences of such a marriage - supports the argument that his marriage to Euphemia was solely a political move at the behest of his father, Robert II. ${ }^{54}$ While it may perhaps be going too far afield to suggest that Alexander Stewart's relationship with Mairead was a strictly monogamous one, it is clear that Alexander Stewart married Euphemia, countess of Ross outside of a preexisting marriage and that doing so prevented her son from direct inheritance of his father's holdings, thereby ensuring a continued stability of Stewart power in the north.

Any scholarly claims that Alexander's marriage to Euphemia, countess of Ross was conducted with designs of personal ambition, are largely unfounded. What seems more likely, is that Alexander married Euphemia to check the power of the Lindsay/Leslie affinity which, upon the death of Walter Leslie, and as an extension the termination of any settlement he had reached with the Stewarts, had the potential to explode. This is supported by the fact that it was the King to whom Euphemia signed several lordships, and it was in turn from the King that some were given to Alexander, possibly as a reward or compensation for carrying out his father's wishes in marrying Walter Leslie's widow. ${ }^{55}$ What is more, it is likely that the Lindsay/Leslie affinity saw the King's hand in these occurrences thus leading to the murder of his men, rather than those of Alexander. Known among the Gaelic population as Alasdair Mor mac an Righ, Great Alexander Son of the king, such a title may have been descriptive, not only of Alexander's influence in being a son of Scotland's king, but also in his political affiliation as a staunch supporter of his father. Although unwilling to make direct conclusions regarding Alexander's relationship with his father, Boardman claims that this byname conveyed his reputation-at least in Gaelic society_-"as a powerful and successful lord whose kindred and allies prospered under his protection." 56 Indeed, rather than retaliating against Alexander for his marriage to Euphemia and the sapping of Lindsay/Leslie influence inherent therein, the affinity attacked the King's own men. One of these victim, Sir John Lyon, thane of Glamis, royal chamberlain, son-in-law and favourite of Robert II, was assassinated by the effective leader of the Lindsay/Leslie affinity, Sir James Lindsay, lord of Crawford. ${ }^{57}$ With the influence of Walter Leslie's inheritances stolen from their grasp, the Lindsay/Leslie affinity sought other means of resisting their Stewart rivals in northern Scotland.

III

Any discussion of Alexander Stewart's actions and their relation to King Robert II's rule is complicated by the actions of the King's other sons. The actions of the King's firstborn, John, earl of Carrick, who would later become Robert III, are particularly important when assessing

53. Boardman, "Lordship in the North-East," 9.

54. Boardman, Early Stewart Kings, 171. Although Boardman does not take his argument as far, he explicitly calls Alexander Badenoch's marriage to Euphemia a "sham."

55. Boardman, Early Stewart Kings, 77-8.

56. Boardman, "Lordship in the North-East," 8.

57. Boardman, Early Stewart Kings, 81. 
Alexander Stewart's loyalty to the King. The Lindsay/Leslie affinity, a longtime disruptor of Stewart power in the north, after being slighted from the Walter Leslie inheritance, turned to the earl of Carrick during Robert II's reign. ${ }^{58}$ Quickly becoming more of a Carrick-Douglas-Lindsay triumvirate, to use Boardman's term, the men that had so long rivalled Stewart power in the north helped Carrick seize the guardianship of Scotland in $1384 .^{59}$ This assumption of power, which may have even included a localized palace coup at Edinburgh, can be seen as having had two disparate outcomes. ${ }^{60}$ On the one hand, the guardianship may have been voluntarily granted by the king who would have been grooming his eldest for his own impending kingship, serving the dual purpose of gradually instituting Carrick's rule, and solving the complications of Robert II's tenuous political relationships in the south of Scotland-relationships with lords who supported Carrick. $^{61}$ One the other hand, this seizure of power at the expense of Robert II's influence may not have been voluntary, and may have been the actions of an ambitious heir, impatient for his inheritance. ${ }^{62}$ While the extent of Carrick's loyalty is beyond the scope of this paper, an analysis of Alexander's situation in all of this indicates the former to be more likely.

By this time, there had been several complaints of unruly populations in the north being the cause of raids, thefts, and violence and disruption in general. ${ }^{63}$ Rather similar to the same complaints resulting in Alexander's arrest alongside his father years earlier, there is a historical consensus that these complaints were directed at Alexander Stewart's use of caterans in the north. ${ }^{64}$ Boardman claims it to be "a largely accidental feature of aristocratic landholding in the north of Scotland that many of those who were most alarmed by the behaviour of Alexander Stewart were also major figures in the south of Scotland, closely connected with Carrick.",65 Contrary to Boardman's suggestion of accidents, if one takes the view that Carrick's adoption of Scotland's guardianship was supported by the King, then it seems evident that Carrick sought to use the differences between Robert II and his rivals to a Stewart advantage. In so doing Carrick could ensure any opposition the Lindsay/Leslie affinity had given Robert would be absent from his own rule and that of future Stewarts. ${ }^{66}$ After using their support to obtain uncontested guardianship, Carrick seems to have completely disregarded any demands the Lindsay/Leslie affinity and any of their allies may have had. Despite their rival claims to lordships in north, and desire for more influence in that area, Carrick granted them no concessions even after a targeted attack against Alexander's holdings in a 1385 general council. ${ }^{67}$ Conversely, Carrick even went so far as to strengthen Badenoch's holdings in northern Scotland. ${ }^{68}$ Additionally, evidence exists suggesting that these complaints against the caterans were based on dissatisfaction with the

58. Ibid., 79-81.

59. Ibid., 82-3, 123-5.

60. Ibid., 124-5. Boardman's argument for the possibility of a palace coup comes from an account in the Book of Pluscarden, an abridgment of Bower's Scotichronicon, which makes reference to "the chief actors in the seizing of King Robert II."

61. Ibid., 123-4.

62. Boardman, Early Stewart Kings, 124-5.

63. Ibid., 83 .

64. Boardman, "Lordship in the North-East," 9-11. Boardman, Early Stewart Kings, 83-8.

65. Boardman, Early Stewart Kings, 124.

66. Ibid., 124-5.

67. Boardman, Early Stewart Kings, 132-3. The existence of such a targeted attack further evinces that it was no accident the same supporters of Carrick and rivals of Robert II in the South were the ones complaining of Alexander Stewart in the north.

68. Ibid., 132-3. 
caterans' land exploitation. ${ }^{69}$ In the position of royal lieutenancy granted by his father, Alexander relied on these cateran forces to uphold the common law. ${ }^{70}$ The instability in the north between Stewart adherents and those of the Lindsay/Leslie affinity were not simply political, but also cultural. ${ }^{71}$ In the frequent absence of many lords from their northern holdings - either due to military careers or southern, more politically active holdings — as well as some new families appointed to northern lordships with no established connections with the Gaelic populations there, it was through the use of caterans that Alasdair Mòr mac an Righ was able to prevent unrest among the native populations of that region - the sort of unrest that had caused turmoil earlier in the fourteenth Century. ${ }^{72}$ In the absence of a justiciar north of the Forth for five years after the death of Alexander Lindsay in 1382, it seems Alexander Stewart may have adopted the responsibilities of that position under jurisdiction of his lieutenancy, thereby leading to his official appointment as justiciar north of the Forth in $1387 .^{73}$

Despite the complaints of the Lindsay/Leslie affinity, and despite their direct support in helping Carrick to obtain the guardianship of Scotland, Carrick did not offer them any noticeable recompense. He seems to have used their dislike of Robert II and Alexander Stewart to further his own position, only to discard their desires afterward. One might be so bold as to suggest that he too saw a threat in their power to that of the Stewarts and, following Robert II and Alexander, was unwilling to provide them with any potential leverage in gaining the upper hand. As Robert II aged however, and Carrick began to take on more power, Robert, earl of Fife, became another figure of authority further complicating the political situation in the north and even stripping Alexander Stewart of the earldom of Buchan.

Without straying beyond the scope of this paper into the complicated relationships between Alexander and all of Robert II's children, one can see an argument for Alexander's use of the raiding Gaelic population in the north not as a violent, chaotic force whose power was exerted toward his own ambitious ends, but rather as a tenuous means of controlling them by employing them as a makeshift policing service in pursuit of stability of the common law and of Stewart power in the north. If these groups would steal cattle and exploit the lands of others, it is still indicative of the stability Alexander provided in that it prevented wanton raiding and plundering throughout the north. ${ }^{74}$

In the final years of King Robert II's reign, the King had fallen ill and Carrick had been injured from a horse's kick resulting in the appointment of Fife as governor of Scotland. ${ }^{75}$ At this time, Fife may have seen an opportunity to secure himself a place of major influence in Scotland at the expense of the other Stewarts. ${ }^{76}$ Likewise, when Carrick adopted guardianship of the nation, he

69. Boardman, "Lordship in the North-East," 9-11.

70. Boardman, Early Stewart Kings, 83-5.

71. Ibid., 88 .

72. Ibid., 88. For the earlier unrest see footnote 9 .

73. Ibid., 79-82.

74. Boardman, "Lordship in the North-East," 9-11.

75. Hector Boece, comp., The Chronicles of Scotland, trans. John Bellenden, eds. Edith C. Batho and H. Winifred Husbands Vol. II, (Edinburgh: William Blackwood \& Sons, 1941), 351-2 (Liber Decimus Sextus, 552).

76. F. J. Amours, ed. The Original Chronicle of Andrew of Wyntoun, Vol. XI, Texts: Book VIII [CH. XXV-XL] and IX (Edinburgh: William Blackwood and Sons, 1908), 264-7 (Cottonian Manuscript IX. viii. 959-71). For more details on the account: Ashley, The House of Stewart, 30-1. Although Ashley does not so much as mention Fife's ambitious drive for further power, he does specify the nature of Carrick's injury having been a horse 
too may have been operating under the desires of personal ambition for furthering his own position. Regardless of the possible motives behind the actions of Alexander Stewart's brothers, Alexander himself remained a stabilizing force in the potentially volatile north of Scotland to the very end of Robert II's reign. In these last days of Robert's reign, Alexander is said to have raided Elgin Cathedral and Aberdeen, and the King, "brokin with lang aige" and "impacient to sustene sa grete oppressioun and cruelte done be his son Alexander, tuke him, quhen he come to his presence, and put him in strang presoun, quhare he remanit to De end of King Robertis deth."77 Though it has long been established that the accuracy of chronicles often takes a backseat to propaganda within them, the reputation they have given Alexander as a harbinger of 'grete oppressioun and cruelte' still lingers today. ${ }^{78}$

IV

Alexander Stewart was closely involved in his father's political life even before he operated as lord of any of his holdings, being briefly imprisoned as a result. Staunchly upholding the Stewart power in the north against that of the Lindsay-Leslie affinity, Alexander even went so far as to marry the widow of his former rival, Sir Walter Leslie, to prevent the opposing affinity from inheriting undue influence. In so doing he may have even violated the terms of a previous marriage to his wife and mother of his children, Mairead inghean Eachainn. Employing one of the very factors of northern instability, the caterans of the large Gaelic population, Alexander Badenoch served as upholder of the common law in the north, earning himself the sobriquet of Alasdair Mòr mac an Righ in his loyalty and dedication to his father and the Stewarts.

Of course, as the few final years of Robert II's reign gave way to further political intriguing among Alexander's brothers, it is difficult to determine where Alexander's loyalties laid. The taking of his titles by Fife, his association with the burning of the Cathedral of Elgin and its nearby village, even the violent actions of Badenoch's sons have played a role in his negative historical reputation as Wolf of Badenoch. Following the strategy of a reinterpretation here employed, future scholarship may well find that these actions too somehow resist the pejorative appellation imparted unto Alexander by the lowland chroniclers.

kick to the head (other sources claim it was a kick to his leg). The severity of the injury may have caused a fear for Carrick's ability to succeed his father-maybe even for his life - and Fife's push for influence may therefore be seen as an effort to establish himself in continuance of Stewart power in place of his older brother. Alas, this paper is not place for an investigation into such a notion.

77. Boece, The Chronicles of Scotland, 353 (Liber Decimus Sextus, 553).

78. For a discussion of the particular propaganda present in lowland chronicles, see Boardman, "Chronicle Propaganda in Fourteenth-Century Scotland: Robert the Steward, John of Fordun and the "Anonymous Chronicle,"” In The Scottish Historical Review Vol. 76, no. 201, Part 1: 'Writing Scotland's History': Proceedings from the 1996 Edinburgh Conference (April 1997): 23-43, http://www.jstor.org/stable/25530736. 


\section{Bibliography}

Amours, F. J., ed. The Original Chronicle of Andrew of Wyntoun. Vol. XI. Texts: Book VIII. [CH. xxv-xl], and ix. Edinburgh: William Blackwood and Sons, 1908.

Ashley, Maurice. The House of Stewart: Its Rise and Fall. London: J.M. Dent and Sons Limited, 1980.

Avignon, Clement VII. Calendar of Papal Letters to Scotland of Clement VII of Avignon 1378-1394. Ed. Charles Burns. Edinburgh: T. And A. Constable Limited, 1976.

Boardman, Steven. "Chronicle Propaganda in Fourteenth-Century Scotland: Robert the Steward, John of Fordun and the "Anonymous Chronicle.'" The Scottish Historical Review Vol. 76, no. 201, Part 1: 'Writing Scotland's History': Proceedings from the 1996 Edinburgh Conference (April 1997): 23-43, http://www.jstor.org/stable/25530736.

---. "Lordship in the North-East: The Badenoch Stewarts, I. Alexander Stewart, Earl of Buchan, Lord of Badenoch." Northern Scotland: The Journal for Scottish Studies, University of Aberdeen. Ed. Payne, L. Peter. Vol. 16 (1996): 1-29.

---. The Stewart Dynasty in Scotland: The Early Stewart Kings: Robert II and Robert III 13711406. East Linton: Tuckwell Press, 1997.

Boece, Hector comp. The Chronicles of Scotland. Translated by John Bellenden. Edited by Edith C. Batho and H. Winifred Husbands Vol. II Edinburgh: William Blackwood \& Sons, 1941.

Grant, Alexander. "Thanes and Thanages, From the Eleventh to the Fourteenth Centuries." In Medieval Scotland: Crown, Lordship and Community, edited by Alexander Grant and Keith J. Stringer, 39-71. Edinburg: Edinburgh University Press, 1993.

Webster, Bruce, ed. The Acts of David II King of Scotts, 1329-1371. Edinburgh: Edinburgh University Press, 1982.

“1315, 1318 Settlement of Succession." In Scottish Historical Documents, edited by Gordon Donaldson, 51-54. New York: Barnes \& Noble, Inc., 1970. 